\title{
Anthós
}

\section{"The Perfidy of the Jews": Visigothic Law and the Catholic Public Sphere}

Jonathan Phillips

Portland State University

Follow this and additional works at: https://pdxscholar.library.pdx.edu/anthos

Part of the History of Religion Commons

Let us know how access to this document benefits you.

\section{Recommended Citation}

Phillips, Jonathan (2013) "'The Perfidy of the Jews": Visigothic Law and the Catholic Public Sphere," Anthós: Vol. 5: Iss. 1, Article 8.

https://doi.org/10.15760/anthos.2013.81

This open access Article is distributed under the terms of the Creative Commons Attribution-NonCommercialShareAlike 4.0 International License (CC BY-NC-SA 4.0). All documents in PDXScholar should meet accessibility standards. If we can make this document more accessible to you, contact our team. 


\section{"The Perfidy of the Jews": Visigothic Law and the Catholic Public Sphere}

Jonathan Phillips

In this essay, I will analyze the Visigothic law code, the Forum judicum, as revised by King Recceswinth in $654 \mathrm{CE}$ and King Erwig in $681 \mathrm{CE}$, in order to examine Visigothic society as envisioned by its lawmakers. In particular, I will focus on the role of Jews in this social framework. While these laws were, of course, normative and not necessarily reflective of any historical reality outside the imaginations of their authors, they can be used to attempt to determine the intent of the Visigothic rulers towards the Jews in their kingdom. To this end, I will provide a brief overview of the treatment of the Jews under Visigothic law before examining scholarship on the language and intent of the church councils leading up to the promulgation of antiJewish legislation, particularly those under the presidency of Isidore of Seville. I will then examine the Liber judicum to ascertain its vision of the Jews in society. I will argue that the Visigothic kings and the bishops of seventh-century Iberia were attempting to engineer an ideal social space in which the interests of church, state, and society were unified, and thus, every social interaction was defined in respect to all three. Pagans, heterodox Christians, and especially Jews could not participate in the religious dimension of this sphere, and thus they had to be excluded from other forms of civic and social participation.

The revised Forum judicum is comprised of twelve books. While King Chindaswinth intended the original Forum judicum to be sufficient for the adjudication of any case that could present itself, it 
was not until Recceswinth's version that the consultation of any other law code was explicitly forbidden. ${ }^{1}$

Recceswinth's revision went so far as to order that the mere possession of another law code would result in the owner being fined thirty pounds of gold. It also imposed the same fine on any judge who did not immediately destroy any copy of such a law code that was confiscated. Among the laws that this new code superseded were the Lex Romana Visigothorum, the laws promulgated by King Alaric II in 506 CE to govern the Hispano- Roman population of Iberia. ${ }^{2}$

Under the Lex Romana Visigothorum, as under the Roman law codes that predated it, Judaism was a legally protected religion. Jews were not only to be considered Roman citizens and live under Roman law, but it was forbidden to interfere with either Jewish religious practice or Jewish judicial autonomy. ${ }^{3} \quad$ This toleration, while technically the state of the law until $654 \mathrm{CE}$, was clearly not always

1 S.P. Scott, ed, Liber judicum, Book II, Title I, Laws VIII, "Of Annulling the Laws of Foreign Nations," and IX, "No One Shall Presume to have in his Possession another Book of Law except this which has just been Published," accessed May 28, 2011 from http://libro.uca.edu/vcode/vg2-1.htm. Because some of the secondary scholarship I have looked at appears to have used translations of the Liber judicum that number the laws slightly differently, I will include the name of each law in addition to its book, title, and law number.

${ }^{2}$ P.D. King, Law and Society in the Visigothic Kingdom (Cambridge: Cambridge University Press, 1972), 10.

${ }^{3}$ Bernard S. Bachrach, Early Medieval Jewish Policy in Western Europe (Minneapolis: University of Minnesota Press, 1977), 4. While Bachrach has been plausibly accused by Norman Roth of overstating the privilege and power of Jews in the Visigothic kingdom, this summary of the rights enumerated under the Lex Romana Visigothorum does not seem problematic. See Norman Roth, Jews, Visigoths and Muslims in Medieval Spain: Cooperation and Conflict (Leiden: E.J. Brill, 1994), 10. Roth describes Bachrach's characterization of a rich and powerful Jewish population in Visigothic Spain as "among the most perverse theories so far advanced." 
respected, even by the Visigothic crown. King Reccared, who led the mass conversion of the Visigoths to Catholicism from Arianism, enforced the decision of the Third Council of Toledo to forcibly baptize the children of mixed Jewish-Christian couples. ${ }^{4}$ Bernard Bachrach has argued that this was not actually an anti-Jewish law because if the child had only a Jewish father, it was not really Jewish, while on the other hand, if a Jewish woman bore the child of a nonJewish man, both the woman and child would be considered dead by the Jewish community, so the child was again not really Jewish. In neither case, according to Bachrach, was a Jewish child being forcibly baptized. $^{5}$

This argument seems specious at best; however, even if it is granted, just twenty-three years later, in 612 CE, King Sisebut ordered the compulsory baptism of the entire Jewish population of the Visigothic kingdom. ${ }^{6}$ This was in explicit contradiction, not only to the laws issued by Alaric II, but also an edict from Pope Gregory I prohibiting the forced conversion of Jews. ${ }^{7} \quad$ The Fourth Council of Toledo in 633 CE deplored forcible baptism but at the same time affirmed that Jews who had been forced to convert against their will must remain Christians. ${ }^{8}$

Even that last vestige of toleration of Judaism evaporated in 638 CE when the Sixth Council of Toledo reaffirmed the policy of forcibly baptizing all Iberian Jews. ${ }^{9} \quad$ In fact, Toledo VI went far beyond Sisbut's policy, not only advocating mandatory baptism, but declaring that the king's right to rule was dependent on his working to

${ }^{4}$ Roth, Jews, Visigoths and Muslims, 10.

${ }^{5}$ Bachrach, Early Medieval Jewish Policy, 5-6.

${ }^{6}$ Roth, Jews, Visigoths and Muslims, 21.

7 Ibid.

${ }^{8}$ Wolfram Drews, The Unknown Neighbour: The Jew in the Thought of Isidore of Seville (Leiden: Brill, 2006), 31.

${ }^{9}$ Ibid., 3.; Roth, Jews Visigoths and Muslims, 31-32. 
eradicate Judaism, stating that, "whoever in time to come shall attain the highest authority in the kingdom shall not ascend the royal throne until he shall have sworn, among other provisions of his oath, not to permit [the Jews] to violate the Catholic Faith."10 That canon goes on to state that any king or bishop who fails to prosecute this mission is subject to anathema and damnation.

Roger Collins has argued that, contrary to the prevailing notion in Visigothic historiography which holds that there were, side by side, separate law codes governing the Gothic and Roman populations, Visigothic law was from the very beginning intended to be territorial, governing the entire population of the kingdom. ${ }^{11}$ In this reading, the status of Jews under the Lex Romana Visigothorum had already been obviated by King Leovigild's Codex Revisus, an updated code based on the Codex Euricianus, the first Visigothic systematic law code. A slightly more compelling argument has been put forward by Isabel Velázquez, namely, that these law codes were indeed intended to be territorial; however, they were also meant to be complimentary, and the old law codes remained in force until explicitly invalidated, as was done by Recceswinth in the Liber iudicum. ${ }^{12}$

Clearly, by the time of the anti-Jewish legislation of Recceswinth and Erwig in the late 7th century, legal toleration of Judaism was

${ }^{10}$ Jeremy DuQ. Adams, trans., "Cannon III of the Sixth Council of Toledo (638)," in Medieval Iberia: Readings from Christian, Muslim, and Jewish Sources, ed. Olivia Remie Constable (Philadelphia: University of Pennsylvania Press, 1997), 22.

${ }^{11}$ Roger Collins, "Law and Ethnic Identity in the Western Kingdoms in the Fifth and Sixth Centuries," in Medieval Europeans: Studies in Ethnic Identity and National Perspectives in Medieval Europe, ed. Alfred P. Smyth (New York: St. Martin's Press, 1998), 6.

${ }^{12}$ Isabel Velázquez, "Jural Relations as an Indicator of Syncretism: From the Law of Inheritance to the Dum Inlicita of Chindaswinth," in The Visigoths from the Migration Period to the Seventh Century: An Ethnographic Perspective, ed. Peter Heather (San Marino: The Boydell Press, 1999), 230. 
already extinct in practice, if not in theory. Some scholars have argued that because of the policies of Sisebut and Bishop Braulio, the president of Toledo VI, references to Jews in subsequent legislation must actually refer to converts and their descendants; however Norman Roth disputes this, citing historical and archeological evidence that a Jewish population remained in Iberia even after the forced conversions. ${ }^{13}$ The laws themselves seem to bear this out, with some of the edicts of the Liber judicum referring to "unbaptized Jews," and one even stating that, "the soil of our kingdom is still only defiled by the infamy of the Jews." ${ }^{14}$ Recceswinth appears to have recognized that forced conversion was not sufficient to create a unified Catholic body politic, and instead decided to issue laws attempting to regulate the role of Jews in his Catholic kingdom.

This decision was certainly influenced by the decisions of the church Councils held during the sixth and seventh centuries. At least by Leovigild's reign, Visigothic kings were explicitly emulating Byzantine policies and ideologies in an attempt to legitimate their own push for a unified realm. ${ }^{15}$ This is reflected in the treatment of the Jews; the status of Jews in the Empire had been deteriorating since the sixth century. ${ }^{16}$ This changing attitude towards Jews and Judaism can perhaps be best seen in the thought of Isidore of Seville, probably the most influential clergyman of the Visigothic kingdom.

The councils over which Isidore presided spent a great deal of time and ink dealing with the Jews of the kingdom. This is notable

${ }^{13}$ Roth, Jews, Visigoths and Muslims, 14.

${ }^{14}$ See, e.g. Scott, ed., Liber judicum, Book XII, Title II, Law III, "Concerning Laws Promulgated on Account of the Wickedness of the Jews," and Law X, "No Jew Shall Testify Against a Christian; and Under What Circumstances the Descendants of Jews may Testify,” accessed May 28, 2011 from: http://libro.uca. edu/vcode/vg12-2.htm.

${ }^{15}$ Drews, The Unknown Neighbour, 13.

${ }^{16}$ Ibid., 7. 
because, as Norman Roth has pointed out, in most of contemporary Europe, the church, at least at a local level, had tolerant if not outright cordial relationships with local Jewish populations. ${ }^{17}$ Isidore himself invested much effort in labeling the Jews "inherently wicked," and "pernicious and perfidious." 18 He also drew heavily on the writings of St. Jerome to associate Jews with the Antichrist in an effort to cement fears of Jews persecuting Christians in the mind of his audience. $^{19}$ Although Isidore's early writings suggest that he at one time held eschatological beliefs derived from Augustine, namely that the Jews were a necessary part of the Apocalypse and must be preserved until then, by the time of Toledo IV, he was working towards their eradication. ${ }^{20}$

Wolfram Drews has examined one specific conciliar canon that is of particular interest to this study. This canon is likely the only extant part of the records of the Third Council of Seville, presided over by Isidore. $^{21}$ The canon notes and condemns the existence of a practice wherein Christian parents would lend their children to Jewish parents when the authorities attempted to force the Jewish parents to have their children baptized. ${ }^{22}$ The Christian children would be rebaptized in the guise of the Jewish children, while the Jewish children would be allowed to escape baptism.

Of particular interest in this canon is the reference to these

${ }^{17}$ Norman Roth, "Bishops and Jews in the Middle Ages," The Catholic Historical Review 80 (1994), 1.

18 Bat-Sheva Albert, "Isidore of Seville: His Attitude Towards Judaism and his Impact on Early Medieval Canon Law,” The Jewish Quarterly Review 80, no. 3/4 (1990), 209-210.

${ }^{19}$ Ibid., 212.

${ }^{20}$ Woflram Drews, “Jews as Pagans?: Polemical Definitions of Identity in Visigothic Spain,” Early Medieval Europe 11 (2002), 206.

${ }^{21}$ Ibid., 190.

22 Ibid., 191. 
unbaptized Jewish children as being raised as pagans. Drews points out that the Latin word paganus originally referred to those who lived outside the city, and carried connotations of backwardness and a lack of connection to the more civilized urban world. ${ }^{23}$ While it did eventually come to almost exclusively refer to non-Christians, Isidore's Etymologies demonstrate that he was familiar with the original meaning and connotations of the word. ${ }^{24}$ Drews further argues that Isidore used this terminology to try to link Jews to heretics. Prior to Isidore, Jews, heretics, and pagans were considered distinct groups, socially, politically, and theologically. ${ }^{25}$

In his Sententiae, Isidore argues that heresies are inherently local, while the Catholic Church is universal. ${ }^{26}$ While the Church comprises the entire oikoumene of the world, heretical groups are private societies, isolated from the realm of public life. Drews argues that Jews were also frequently framed in these terms of private versus public societies. This opposition is further reflected in the repeated use of the word "perfidia" to describe Jews; while it can literally mean simply "unbelief," Drews argues that, based on a wide reading of Isidore's works, it would be better translated as "apostasy," "rebellion," or "treason."27 In this reading, participation in these private societies is not only seen as socially corrosive, but as acting in direct and deliberate opposition to the state.

The anti-Jewish legislation in the Liber judicum represented a new strategy towards a long-standing goal: the establishment of a unified, universal Visigothic social sphere. The dissolution of the social barriers between Romans and Goths, and orthodox Christians

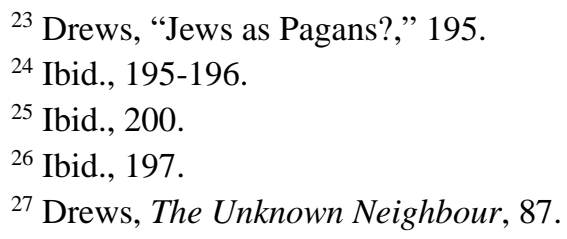


and Arians had been an aim of the Visigothic crown at least since the reign of Leovigild. ${ }^{28}$ It has even been argued that after the mid-sixth century it makes no sense to speak of studying the "Goths" as a distinct entity in the Visigothic kingdom; the society was by that point an indissoluble mix of Gothic and Roman ethnic identities and social structures. $^{29}$

This strategy to bring about a catholic (in all senses of the word) public sphere through the law code relied on two approaches. First was the insistence on the universality of the laws, not only in that they governed everyone, but also in that all possible social interactions were to be regulated within it. The more novel aspect appeared in the second approach, which involved laws that were indirectly rather than directly aimed at the dissolution or marginalization of groups acting outside the proper social milieu as defined elsewhere in the Liber judicum. This second approach reflected an increased anxiety over activities taking place within private spheres, primarily within the religious realm, where it was recognized that one could privately practice rites at odds with one's public profession of faith. This anxiety over private spheres of activity was present, albeit to a lesser extent, towards other social arenas, including familial relationships.

The intent towards universality in the Liber judicum is explicit and obvious. Book I contains an exposition of its underlying legal philosophy and a guideline for issuing legislation. In this philosophy, the law is to be "fully and explicitly set forth, that perfection, and not partiality, may be secured.”30 Book II lays out legal procedure, and

${ }^{28}$ King, Law and Society in the Visigothic Kingdom, 13-14.

${ }^{29}$ Ian Wood, "Social Relations in the Visigothic Kingdom from the Fifth to the Seventh Century: The Example of Mérida," in The Visigoths from the Migration Period to the Seventh Century: An Ethnographic Perspective, ed. Peter Heather (San Marino: The Boydell Press, 1999), 193.

30 Scott, ed., Liber judicum, Book I, Title II, Law I, "What the Lawmaker Should Observe in Framing the Laws,” accessed May 30, 2011 from: http://libro. 
stipulates that all criminal and civil cases fall under the jurisdiction of the king or royally appointed judges or their delegates. ${ }^{31}$ In keeping with the religious character of the Visigothic state, appeal is only possible according to the Liber judicum if a bishop decides that a judge has decided unjustly; in that case the bishop can demand that the judge re-evaluate his decision or even issue a new, binding decision himself. ${ }^{32}$

Much of the rest of the Liber judicum is simply concerned with laying out the framework for social institutions and addressing as many of the possible conflicts as the authors can imagine. For example, the book on marriage deals with the legal status of every conceivable combination of marriage and remarriage between freemen, freewomen, freedmen, freedwomen, slaves, people of different ages, people of various levels of consanguinity, victims and perpetrators of kidnapping or rape, and adulterers, while also taking into account whether or not a potential couple had parental support, were engaged to each other, were engaged to other people, or had adequate dowries. ${ }^{33}$ Other sections dealing with business transactions, property disputes, and accidental or malicious injury go into similar levels of detail.

In compliment to the universal nature of the philosophy and

uca.edu/vcode/vg1-2.htm.

${ }^{31}$ Scott, ed., Liber judicum, Book II, Title I, Law XIII, “It Shall be Lawful for No One to Hear and Determine Causes Except Those Whom either by the King, the Parties by Voluntary Consent, or the Judge, shall have Invested with Judicial Powers,” and Law XV, “Judges Shall Decide Criminal as well as Civil Causes” accessed May 30, 2011 from: http://libro.uca.edu/vcode/vg1-2.htm

32 Scott, ed., Liber judicum, Book II, Title I, Law XXVIII, “Concerning the Power, conferred upon Bishops, of Restraining Judges who Decide Wrongfully,” accessed May 30, 2011 from: http://libro.uca.edu/vcode/vg1-2.htm.

33 Scott, ed. Liber judicum, Book III, “Concerning Marriage,” accessed May 30, 2011 from: http://libro.uca.edu/vcode/bk3.htm. 
regulations of the Liber judicum are its efforts at disempowering private spheres of activity. This is perhaps most apparent in its suppression of non-orthodox religious sects as will be discussed below, or in its aforementioned rejection of any attempts by third parties to adjudicate disputes outside of those sanctioned by the king or his agents; however, this tendency also manifests itself in subtler ways. One of these is found in the marriage laws, particularly the prohibition against incest and the lifting of the ban on Roman/Goth miscegenation. Marriage in the Visigothic kingdom was not only a social arrangement, but also had significant economic aspects. Dowries were mandatory, and could be up to ten percent of a bridegroom's property (or that of his parent or benefactor). ${ }^{34}$ Women, likewise, were permitted to gift their new husbands up to ten percent of their property, or their parents'. This law is framed in terms of the nobility; however, at the end it is made explicit that it applies to all marriages and that however much the family of the bridegroom possesses, they are to give up to ten percent of it to the bride.

This transfer of property, sometimes mutual, was certainly of great importance in fostering a unified arena of economic exchange. Lifting the ban on miscegenation, then, would have served not only to integrate the Goths and the Romans ethnically, but economically as well. The idea that this integration was being deliberately intended to stimulate wider exchange and break up closed economic communities, particularly among noble families, is supported by the legal pressure exerted by the laws against incest to marry out.

Incest is defined in the Liber judicum as marriage or "relations" with anyone "related even to the sixth degree." ${ }^{35}$ The Visigothic

34 Scott, ed., Liber judicum, Book III, Title I, Law VI, "What Property the Dowry shall consist of,” accessed May 30, 2011 from: http://libro.uca.edu/vcode /bk3.htm.

${ }^{35}$ Scott, ed., Liber judicum, Book II, Title V, Law I, “Concerning Incestuous and Adulterous Marriages in General,” accessed May 30, 2011 from: 
understanding of degrees of consanguinity does not precisely line up with modern ideas of degrees of relatedness; however, there is a law in Book IV detailing, if somewhat ambiguously, the meanings of the "degrees of relationship."36

According to these laws, the sixth degree of relationship includes:

[F]irst, the great-great-great-great-grandfather and the greatgreat-great-great-grandmother, then the great-great-greatgreat-grandson and the great-great-great-greatgranddaughter; next, in the collateral line, the son and the daughter of a great-grandchild of the sister; the sons of a father's brother and the sons of a father's sister; cousins on both sides of the house, paternal and maternal great-aunts, and the grandsons and granddaughters of paternal greatuncles and maternal great-aunts. To whom are added, in the collateral line, the children of the great-uncles and the greataunts of both father and mother; that is to say, of the brother and the sister of the paternal great-great-grandfather, and of the brother and sister of the maternal great-greatgrandmother. No better explanation of this matter can be given than we have written above. ${ }^{37}$

In the context of the rest of the laws on consanguinity, it appears that this complexly worded statute prohibits marriage between any two people who share an ancestor going back four generations.

Given that the penalties for violating the prohibition against

http://libro.uca.edu/vcode/bk3.htm.

${ }^{36}$ Scott, ed., Liber judicum, Book IV, Title I, "Concerning the Degrees of Relationship,” accessed May 31, 2011 from: http://libro.uca.edu/vcode/vg4-1.htm.

${ }^{37}$ Scott, ed., Liber judicum, Book IV, Title I, Law VI, "The Limits of the Sixth Degree,” accessed May 31, 2011 from: http://libro.uca.edu/vcode/vg4-1.htm. 
incest, which included permanent imprisonment in a monastery and the confiscation of all of one's property, this law provided significant incentive to marry outside one's family's intimate circles. This in turn presumably worked to prevent tight-knit groups of families, particularly noble families, from isolating themselves and potentially building power bases to rival that of the king. While this policy can be and frequently is viewed simply in terms of power struggles between a monarch and an aristocracy, the conflation of the interests of the king and the interests of the state in the Liber judicum make the opposition of public and private interests a useful and interesting way to frame it.

This conflict between public and private spheres of activity is implicit in many of the laws in the Liber judicum; however, in its discussion of Jews and heretics, this conflict is made explicit. Book XII of the Visigothic law code contains two sections that supposedly deal with all heretics and non-Christians; however, the vast majority of these laws refer only to Jews. Title II of Book XII contains Recceswinth's eighteen anti-Jewish laws, while Title III contains Erwig's twenty-eight. Recceswinth is clear in the first of his antiJewish statutes that these laws deal with "the secret recesses of minds," as opposed to public confessions of faith. ${ }^{38}$ The definition of incest is also widened for Jews under Recceswinth's laws to include the seventh degree of kinship, presumably to disrupt what were most likely small, tightly knit communities in which most people would be related to that degree. ${ }^{39}$ Recceswinth's concern over the possibility

38 Scott, ed., Liber judicum, Book XII, Title II, Law I, “Laws Having Been Given to True Believers, it is Now Necessary to Place Restraints upon Infidels,” accessed May 31, 2011 from: http://libro.uca.edu/vcode/vg12-2.htm.

${ }^{39}$ Scott, ed., Liber judicum, Book XII, Title II, Law VI, “Jews shall not Contract Marriage According to their Custom,” accessed May 31, 2011 from: http://libro.uca.edu/vcode/vg12-2.htm. 
of Jewish practice being carried out in private was such that any citizen who knew of Jewish rituals or observances and did not report them would be subject to the same penalty as the secret Jew: being stripped of their possessions and sent into permanent exile. ${ }^{40}$

The anti-Jewish legislation of Recceswinth is primarily concerned with the activities of Jews in private; the only laws regarding Jewish interactions with Christians are laws prohibiting Jewish ownership of Christian slaves, Jews prosecuting or testifying against Christians, and Christians from defending Jews. The Erwigian anti-Jewish laws, on the other hand, deal not only with those same topics, but also the exclusion of Jews from positions of authority and, more significantly, the legally necessary steps to ensure that Jewish conversion to Christianity is legitimate.

One of the most interesting laws in Book XII of the Liber judicum is that prohibiting Jews, whether unbaptized or converted, from testifying in trials. ${ }^{41}$ This law is framed in terms of perjury, conflating knowingly false testimony in legal matters with Jewish identity. This conflation comes from the association of "faith" and "testimony," a connection that is likely inevitably inherent in an evangelical religion such as Christianity. Isidore himself is explicit that these two ideas are inextricably intertwined, and traces that idea to Cicero. ${ }^{42}$ John Chrysostom, the fourth-fifth century Archbishop of Constantinople, and one of the most significant and influential theologians of the early Church, stated in his anti-Jewish homilies that

${ }^{40}$ Scott, ed., Liber judicum, Book XII, Title II, Law IV, "Concerning the Extirpation of the Errors of the Jews in General,” accessed May 31, 2011 from: http://libro.uca.edu/vcode/vg12-2.htm.

${ }^{41}$ Scott, ed., Liber judicum, Book XII, Title II, Law X, “No Jew shall Testify Against a Christian; and Under what Circumstances the Descendants of Jews may Testify,” accessed May 31, 2011 from: http://libro.uca.edu/vcode/vg12-2.htm.

42 Drews, The Unknown Neighbour, 47. 
religion is spread through testimony rather than exhortation. ${ }^{43}$ Chrysostom went on to argue that Christianity had many witnesses, from the Old Testament prophets to Jesus himself, while the Jews have no witnesses; therefore, the Jews are not to be believed.

Although it is unclear whether or not Isidore had direct access to Chrysostom's sermons against the Jews, he was certainly aware of Chrysostom's notorious attitudes and the traditions they informed. ${ }^{44}$ It is interesting to note that the attitudes of Chrysostom, Isidore, and the other church fathers responsible for the conciliar canons prohibiting Jewish testimony on the bases of the perfidy and untrustworthiness of the Jews were operating under a theological attitude towards the Jews in direct opposition to that of Augustine of Hippo. Augustine was arguably the most significant theologian in Church history, and certainly seen as such by the Visigothic church. ${ }^{45}$

Augustine's position regarding the Jews was that they acted as the "librarians" or "witnesses" to the Christians, preserving the books and knowledge of the Old Testament until the beginning of the Christian era. ${ }^{46}$ In this theology, the Jews were significant to Christian history precisely because of their fidelity and recognition of the truth. These truths preserved by the Jews could be used to argue against the pagans, whom Augustine saw as the true threat to Christianity. ${ }^{47}$ The switch on the part of Isidore and his contemporaries from Augustinian attitudes towards the Jews towards one more in line with that of Chrysostom seems likely to have been

${ }^{43}$ John Chrysostom, “Adversus Judaeos,” in The Medieval Sourcebook, accessed May 30, 2011 from: http://www.fordham.edu/halsall/source/chrysostomjews6.html.

\footnotetext{
${ }^{44}$ Drews, The Unknown Neighbour, 175.

${ }^{45}$ Ibid., 27.

${ }^{46}$ Ibid., 27.; Drews, “Jews as pagans?” 192.

${ }^{47}$ Drews, “Jews as Pagans?” 192.
} 
part of their efforts to bring about a unified and universal Christian social sphere.

It seems likely, then, that one of the driving factors behind the anti-Jewish legislation in the Visigothic law code was the tension between homogeneity and inclusivity in a supposedly universal society. The Visigothic lawmakers' desire for a public sphere that was catholic and Catholicism forced them to deal with the Jews as what Drews refers to as a "permanent anomaly" in their ordered society. ${ }^{48}$ When forced integration and extirpation failed to produce religious and cultural homogeneity, the kings and bishops turned to marginalization and exclusion. While it is almost certain that these ideals were not reflected in the day to day life of the people of the Visigothic kingdom, where Jews seem to have lived side-by-side with Christians, and later, Muslims, until their expulsion in 1492, these laws and the councils behind them provide an interesting window into the ideal structure of Visigothic society according to those responsible for shaping it.

\section{Bibliography}

Adams, Jeremy duQ. "Canon III of the Sixth Council of Toledo (638).” In Medieval Iberia: Readings from Christian, Muslim, and Jewish Sources. Edited by Olivia Remie Constable, 21-22. Philadelphia: University of Pennsylvania Press, 1997.

Albert, Bat-Sheva. "Isidore of Seville: His Attitude Towards Judaism and his Impact on Early Medieval Canon Law.” The Jewish Quarterly Review 80, no. 3/4 (1990): 207-220.

Bachrach, Bernard S. Early Medieval Jewish Policy in Western Europe.

Minneapolis: University of Minnesota Press, 1977.

Collins, Roger. "Law and Ethnic Identity in the Western Kingdoms in the Fifth and Sixth Centuries." In Medieval Europeans: Studies in Ethnic Identity and

${ }^{48}$ Drews, The Unknown Neighbour, 30. 
National Perspectives in Medieval Europe. Edited by Alfred P. Smyth, 1-23. New York: St. Martin's Press, 1998.

---. "Visigothic Law and Regional Custom in Disputes in Early Medieval Spain.” In The Settlement of Disputes in Early Medieval Europe, edited by Wendy Davies and Paul Fouracre, 85-104. Cambridge: Cambridge University Press, 1986.

---. Visigothic Spain: 409-711. Malden: Blackwell Publishers, 2004.

Drews, Wolfram. "Jews as Pagans?: Polemical Definitions of Identity in

Visigothic Spain.” Early Medieval Europe 11 (2002): 189-207.

---. The Unknown Neighbour: The Jew in the Thought of Isidore of Seville. Leiden:

Brill, 2006. John Chrysostom. "Eight Homilies Against the Jews." In Internet

Medieval Sourcebook, edited by Paul Halsall. Accessed April, 28, 2011

from: http://www.fordham.edu/halsall/source/chrysostom-jews6.html.

King, P.D. Law and Society in the Visigothic Kingdom. Cambridge: Cambridge

University Press, 1972.

Koon, Sam and Jamie Wood. "Unity from Disunity: Law, Rhetoric and Power in the

Visigothic Kingdom.” European Review of History 16 (2009): 793-808.

Roth, Norman. "Bishops and Jews in the Middle Ages." Catholic Historical Review 80 (1994): 1-17.

---. Jews, Visigoths and Muslims in Medieval Spain: Cooperation and Conflict.

Leiden: E.J. Brill, 1994.

Scott, S.P., ed. Liber judicum. Boston: Boston Book Company, 1910. Accessed through The Library of Iberian Resources Online at: http://libro.uca.edu/vcode/ visigoths.htm.

Stocking, Rachel. Bishops, Councils and Consensus in the Visigothic Kingdom, 589633. Ann Arbor: University of Michigan Press, 2000.

Velázquez, Isabel. "Jural Relations as an Indicator of Syncretism: From the Law of Inheritance to the Dum Inlicita of Chindaswinth," In The Visigoths from the Migration Period to the Seventh Century: An Ethnographic Perspective, edited by Peter Heather, 225-270. San Marino: Boydell Press, 1999.

Wood, Ian. "Social Relations in the Visigothic Kingdom from the Fifth to the Seventh Century: The Example of Mérida." In The Visigoths from the Migration Period to the Seventh Century: An Ethnographic Perspective, edited by Peter Heather, 191-224. San Marino: Boydell Press, 1999. 